\title{
The Characteristics of Preeclampsia with Severe Features
}

\author{
Karakteristik Preeklamsia dengan Tanda Perburukan
}

\author{
JM Seno Adjie, Fredy Lisnan, Yosep Sutandar \\ Department of Obstetrics and Gynecology \\ Faculty of Medicine Universitas Indonesia/ \\ Dr. Cipto Mangunkusumo Hospital \\ Jakarta
}

\begin{abstract}
Objective: To describe the characteristics of preeclampsia with severe features and their risk factors.

Method: This study was a retrospective medical record review of demographic characteristics, obstetric and medical data of preeclampsia with severe features in Dr. Cipto Mangunkusumo Hospital from July to December 2014.

Result: There were 1,013 deliveries which 183 patients of them were diagnosed as preeclampsia with severe features (18.06\%). The study showed $67.76 \%$ were 20 - 35 years old, most of them were multiparity, and $41.53 \%$ were preterm labor with 28 - 336 weeks of gestation then followed by $24.59 \%$ were 34 - 366 weeks' gestation. Majorities of preeclampsia with severe features patients were without complication either to the mother or the baby. There were 1 case of maternal mortality and 15 cases of intra uterine fetal death (IUFD). There were $73.77 \%$ cases delivering by cesarean section. The complication of the mother in preeclampsia with severe features was related significantly to the complication in baby, such as preterm delivery. Besides, women's age and parity had significant relationship with baby complication.
\end{abstract}

Conclusion: There is association of complication in preeclampsia with severe features women with baby, namely preterm delivery. Besides, women's age and parity is related to complication of baby.

[Indones J Obstet Gynecol 2016; 4-4: 179-182]

Keywords: complication, preeclampsia, risk factors

\begin{abstract}
Abstrak
Tujuan: Untuk mendeskripsikan karakteristik preeklamsia dengan tanda perburukan dan faktor risikonya.

Metode: Penelitian ini merupakan penelitian retrospektif mengenai karakteristik preeklamsia dengan tanda perburukan pasien-pasien obstetri dan ginekologi di RS Dr. Cipto Mangunkusumo dari bulan Juli 2014 sampai Desember 2014.

Hasil: Terdapat 1013 total persalinan selama studi dilakukan, dan di antaranya terdapat 183 (18,06\%) kasus preeklamsia dengan tanda perburukan. Dari penelitian ini didapatkan $67,76 \%$ pasien berada di rentang umur 20-35 tahun dan mayoritas dari pasien tersebut adalah multiparitas; dan 41,53\% adalah persalinan preterm pada $28-336$ minggu gestasi dan diikuti 24,59\% persalinan preterm pada 34-366 minggu gestasi. Mayoritas pasien dengan preeklamsia dengan tanda perburukan tidak mengalami komplikasi, baik pada ibu maupun bayinya. Didapatkan pula 1 kematian maternal dan 15 kematian fetus dalam rahim. Terdapat sekitar 73,77\% kasus yang dilahirkan melalui seksio sesarea. Preeklamsia dengan tanda perburukan dengan komplikasi secara signifikan berhubungan dengan persalinan preterm. Selain itu, usia maternal dan status paritas dengan preeklamsia dengan tanda perburukan dan komplikasi terhadap bayi.

Kesimpulan: Preeklamsia dengan tanda perburukan dengan komplikasi secara signifikan berhubungan dengan persalinan preterm. Selain itu, umur maternal dan status paritas secara siginifikan berhubungan dengan preeklamsia dengan tanda perburukan dan komplikasi terhadap bayi.

[Maj Obstet Ginekol Indones 2016; 4-4: 179-182]

Kata kunci: faktor risiko, komplikasi, perburukan, preeklamsia
\end{abstract}

Correspondence: JM Seno Adjie, jmseno@hotmail.com

\section{INTRODUCTION}

Maternal mortality is a health indicator which describes the condition of its country. It shows the very wide gap between rich and poor, urban and rural areas among countries in the world. World Health Organization (WHO) attempts to reduce the maternal mortality rate (MMR) around the worlds, including Indonesia through Millennium Development Goals (MDGs) continued by Sustainable Development Goals (SDGs). ${ }^{1}$ Based on data from Indonesia Department of Health, preeclampsia is one of three commonest cause for maternal death. ${ }^{2}$
Preeclampsia is defined as a syndrome consisting of hypertension with blood pressure more or equal to $140 / 90$ and/or proteinuria more or equal to positive 1 . These signs are appeared at 20 weeks of gestational age and resolved at 12-week postpartum. While, preeclampsia with severe features is known as hypertension with blood pressure more or equal to $160 / 110$ and/or proteinuria more or equal to positive 2 . The onset is similar to preeclampsia. The risk factors for preeclampsia are multifactorial. Several risk factors which have been identified are molar pregnancies, nulliparity, aged less than 20 years old or over 35 years old, more 
than one fetus, chronic hypertension, diabetes mellitus and renal disease. Besides, preeclampsia is also influenced by parity, genetic, and environmental factors. ${ }^{1,3}$

The incidence of preeclampsia was relatively stable between 4 and 5 cases per 10,000 live births in developed countries. In the developing countries, the incidence of preeclampsia was around 3.9\%. Meanwhile, in Dr. Cipto Mangunkusumo hospital as the center of referral hospital in Indonesia, the incidence in 2008-2009 was $16.3 \%{ }^{4}$ The MMR was varied from $0 \%$ to $4 \%$. Increased maternal death due to complications involves various body systems, such as intracerebral hemorrhage and pulmonary edema. Preeclampsia has also an impact for the baby ending to the infant death. The perinatal mortality rate was ranged from $10 \%$ to $28 \%$. Prematurity, growth retardation, and increased risk of abruption placenta often cause the perinatal death. Approximately less than 75\% eclampsia occurs antepartum and $25 \%$ in the postpartum. Almost all cases (95\%) antepartum eclampsia are happened in the third trimester. ${ }^{5}$
The incidence of preeclampsia occurs on $5 \%$ population of white women, $9 \%$ population of women Hispanic, $11 \%$ in women African-American. The incidence on nullipara reaches $3-10 \%$, maternal weight affects the risk of preeclampsia from 4.3 to $13.3 \%{ }^{6}$ Women with preeclampsia in their first pregnancy have a greater risk to be preeclampsia in the next pregnancy. Smoking during pregnancy is associated with reduced risk of hypertension in pregnancy. ${ }^{6}$ Therefore, this study aims to describe the characteristics of preeclampsia with severe features and their risk factors

\section{METHODS}

This study was a retrospective medical record review about preeclampsia with severe features in Dr. Cipto Mangunkusumo Hospital. All preeclampsia with severe features records between July and December 2014 were collected and reviewed. We did the statistical analysis using SPSS software. We used chi square to determine the relative risk between several independent variables and fetal complication.

Table 1. The Characteristics of Preeclampsia with Severe Features in Dr. Cipto Mangunkusumo Hospital

\begin{tabular}{|c|c|c|c|}
\hline Characteristics & & $\mathbf{N}$ & $\%$ \\
\hline \multirow[t]{3}{*}{ Age (years old) } & $<20$ & 10 & 5.46 \\
\hline & $20-35$ & 124 & 67.76 \\
\hline & $>35$ & 49 & 26.78 \\
\hline \multirow[t]{3}{*}{ Parity } & $<1$ & 63 & 34.43 \\
\hline & $2-5$ & 120 & 65.57 \\
\hline & $>5$ & 0 & 0 \\
\hline \multirow[t]{5}{*}{ Gestational Age (weeks) } & $20-276$ & 8 & 4.37 \\
\hline & $28-33^{6}$ & 52 & 28.42 \\
\hline & $34-36^{6}$ & 45 & 24.59 \\
\hline & $37-41^{6}$ & 76 & 41.53 \\
\hline & $>=42$ & 2 & 1.09 \\
\hline \multirow[t]{4}{*}{ Maternal Complication } & None & 144 & 78.69 \\
\hline & HELLP syndrome & 27 & 14.75 \\
\hline & Eclampsia & 7 & 3.83 \\
\hline & HELLP syndrome and Eclampsia & 5 & 2.73 \\
\hline \multirow[t]{4}{*}{ Fetal Complication } & None & 151 & 82.52 \\
\hline & IUGR & 19 & 10.38 \\
\hline & Poor APGAR score & 10 & 5.46 \\
\hline & IUGR and Poor APGAR score & 3 & 1.64 \\
\hline \multirow[t]{2}{*}{ Maternal Mortality } & Life & 182 & 99.45 \\
\hline & Dead & 1 & 0.55 \\
\hline \multirow[t]{2}{*}{ Fetal Mortality } & Life & 168 & 91.80 \\
\hline & Dead & 15 & 8.20 \\
\hline \multirow[t]{2}{*}{ Mode of Delivery } & Vaginal & 48 & 26.23 \\
\hline & Cesarean section & 135 & 73.77 \\
\hline
\end{tabular}




\section{RESULTS}

There were 183 cases of preeclampsia with severe features among 1,013 pregnant women recorded coming to Dr. Cipto Mangunkusumo hospital at Emergency Unit. The majority of preeclampsia with severe features cases was among 20-35 years old and multiparity (65.57\%). Almost half of women $(41.53 \%)$ were in term gestational age, followed by $28-36^{6}$ weeks of gestation around $28.42 \%$, and $24.59 \%$ women was in $34-36^{6}$ weeks of gestation. The majority of preeclampsia with severe features cases had no complication either the mother or the baby; there were only 27 cases having HELLP syndrome, 7 cases with eclampsia, and 5 cases with both HELLP syndrome and eclampsia. In term of baby complication, only $17.48 \%$ baby were born with complication consisting of intrauterine growth retardation (IUGR), poor APGAR score, IUGR and APGAR score in each percentage of $10.38 \%, 5.46 \%, 1.46 \%$; respectively. In this study, there was one maternal death with the charac- teristics of less than 20 years old, primigravida, at term of gestation with HELLP syndrome and lung edema. The baby was delivered by cesarean section having poor APGAR score. Besides, there were 15 intrauterine fetal death (IUFD) cases. Meanwhile, around $73.77 \%$ preeclamptic women with severe features were delivered by cesarean section.

Table 2 showed that there was significant association between fetal and maternal complication of preeclampsia with severe features.

Based on statistics, maternal age had significant relationship with fetal complication; whereas, young maternal age ( $<20$ years old) had a tendency of increasing 2.2 times risk to have fetal complication (shown in Table 3).

Table 4 depicted that there was significant association between parity and fetal complication; whereas, nulliparity was considered as the risk factor for the complication.

Table 2. Relationship between Fetal and Maternal Complication of Preeclampsia with Severe Features

\begin{tabular}{lccccc}
\hline \hline \multirow{2}{*}{ Maternal Complication } & \multirow{2}{c}{ Total } & RR & CI 95\% & p-value \\
\cline { 2 - 5 } & With Complication & Without Complication & & & \\
\hline With & 12 & 27 & 39 & 2.215 & $0.035-0.303$ \\
Without & 20 & 124 & 144 & 1 & \\
Total & 32 & 151 & 183 & & \\
\hline \hline
\end{tabular}

Table 3. Relationship between Fetal Complication and Maternal Age

\begin{tabular}{|c|c|c|c|c|c|c|}
\hline \multirow{2}{*}{ Maternal Age } & \multicolumn{2}{|c|}{ Fetal } & \multirow{2}{*}{ Total } & \multirow{2}{*}{$\mathbf{R R}$} & \multirow{2}{*}{ CI 95\% } & \multirow{2}{*}{ p-value } \\
\hline & With Complication & Without Complication & & & & \\
\hline$<20$ years old & 4 & 6 & 10 & 2.156 & $0.004-0.481$ & 0.050 \\
\hline 20 - 35 years old & 23 & 101 & 124 & 1 & & \\
\hline$>35$ years old & 5 & 44 & 49 & 0.55 & $0.026-0.224$ & 0.118 \\
\hline Total & 32 & 151 & 183 & & & \\
\hline
\end{tabular}

Table 4. Relationship between Fetal Complication and Parity

\begin{tabular}{lcccccc}
\hline \hline \multirow{2}{*}{ Parity } & \multicolumn{2}{c}{ Fetal } & Total & RR & CI 95\% & p-value \\
\cline { 2 - 4 } & With Complication & Without Complication & & & & $0.014-0.03$ \\
With & 17 & 46 & 63 & 2.158 & 0.014 \\
Without & 15 & 105 & 120 & 1 & \\
Total & 32 & 151 & 183 & & \\
\hline \hline
\end{tabular}




\section{DISCUSSION}

The number of preeclampsia with severe features patients who came to Dr. Cipto Mangunkusumo hospital from July to December 2014 were 183 women of 1,013 pregnant women. The percentage was around $18.06 \%$. Compared with the period of 2008-2009 which was only $16.3 \%$, it meant that there was an increasing around $2 \%$ within 5 years. ${ }^{4}$ It might be caused by the deterioration of the pregnant women's health condition in Jakarta. Apart from that, in the era of national health coverage (Jaminan Kesehatan Nasio-nal JKN), there is an increasing awareness of people to seek treatment at health center so that the number of diagnosed case, especially preeclampsia raise in hospital.

Of the characteristics, the dominance of women's age was between 20 and 35 years old (67.76\%) and certainly, the number of maternal and fetal complication due to preeclampsia were dominant in that age group, such as HELLP syndrome (70.37\%), eclampsia (85.71\%), 80\% for both eclampsia and HELLP syndrome. While, the fetal complication consisting of IUGR, poor APGAR score, IUGR with poor APGAR score was $73.68 \%, 60 \%, 100 \%$; respectively in the age group of 20-35 years old. Although maternal age was not significantly associated with complication of preeclampsia with severe features, the women less than 20 years old had a tendency for complication of preeclampsia with severe features about 1.2 times greater than the maternal age of 2035 years old. Besides, maternal age had a significant relationship with fetal complication; whereas, women less than 20 years old tended to increase 2.2 times of fetal complication. It is quite reasonable according to the habit in capital city, a lot of women postpone their pregnancy for the career.

Pregnancy in any parity group should be noticed to be preeclampsia. Based on statistical calculation, the result showed there was no association between parity and maternal complications in preeclampsia, although parity was related to fetal complication. This might occur due to other factors that have more influence on pregnant women than only a parity.

From the study, most of women were at term gestational age. There were probably due to lack of awareness among pregnant women for doing antenatal care (ANC) or lack of screening facility in the primary health services. Preeclamptic patients who came to the emergency unit on Dr. Cipto Mangunkusumo hospital were generally without complications. The complication of preeclampsia with severe features were HELLP syndrome (14.57\%), eclampsia (3.82\%) and both HELLP syndrome and eclampsia $(2.73 \%)$. Statistical analysis showed that preterm pregnancy complication was related to the incidence of preeclampsia with severe features. The analytic issue was due to the lack of awareness for doing ANC, poor economic society, and the number of children. In women with preeclampsia, the complication could be seen to the dominance of HELLP syndrome at $28-33^{6}$ weeks of gestation as much as $8.74 \%$ of the total preeclampsia's incidence.

Preeclampsia caused one maternal death and 15 IUFD in the second semester during 2014. Of the IUFD cases, 12 cases were obtained in women with preeclampsia without complications; while, complication of preeclampsia with HELLP syndrome only caused one IUFD. Eclampsia and HELLP syndrome contributed to 2 patients with IUFD. In linear regression calculation, it was also found that there was no association between complication of preeclampsia and IUFD. Maternal complication of preeclampsia should not be associated with IUFD. Actually, IUFD itself was associated with the prematurity.

\section{CONCLUSION}

In Dr. Cipto Manggunkusumo Hospital, there are 183 cases of preeclampsia with severe features among 1,013 patients that come to emergency unit from July to December 2014. Preeclamptic women with severe features are associated with preterm delivery. Apart from that, women's age and parity have significant relationship with severe features preeclampsia and the complication of the baby.

\section{REFERENCES}

1. WHO. Millennium Development Goals: at a Glance 2010.

2. Indonesia KKR. Profil Kesehatan Indonesia 2012. In: Suprinatoro, Primadi O, Hardhana B, Budijanto D, Sitohang V, Soenardi TA, editors. Jakarta: Kementerian Kesehatan Republik Indonesia; 2013.

3. WHO. Mother-baby package: implementing safe motherhood in countries 1994. (accessed 2014).

4. Kusuma T, Affandi B, Ocviyanti D, Prihartono J. Manajemen risiko dalam pelayanan pasien preeklampsia berat (PEB)/ eklampsia di instalasi gawat darurat RSUPNCM. Maj Obstet Ginekol Indones 2009; 33(3): 135-42.

5. WHO. WHO recommendation for prevention and treatment of pre-eclampsia and eclampsia. WHO recommendation, 2011. Cunningham F, Gant N, al e. Williams obstetrics. 24 ed. New York: McGraw-Hill; 2014.

6. Sibai B, Dekker G, Kupfermin M. Pre-eclampsia. Lancet (London, England) 2005; 365: 785-99. 